\title{
Annual antifreeze cycles in Newfoundland, New Brunswick and Long Island winter flounder Pseudopleuronectes americanus
}

\author{
G. L. Fletcher ${ }^{1}$, K. Haya ${ }^{2}$, M. J. King ${ }^{1}$ and H. M. Reisman ${ }^{3}$ \\ ${ }^{1}$ Marine Sciences Research Laboratory, Memorial University of Newfoundland, St. John's, Nfld., Canada \\ ${ }^{2}$ Biological Station, Department of Fisheries and Oceans, St. Andrews, New Brunswick, Canada \\ ${ }^{3}$ Division of Natural Sciences, Southampton College of Long Island, University, Southampton, New York 11968, USA
}

\begin{abstract}
Annual cycles of plasma antifreeze peptide levels were compared in winter flounder Pseudopleuronectes americanus from 3 areas: Conception Bay, Newfoundland; Passamaquoddy Bay, New Brunswick; and Shinnecock Bay, Long Island, New York. Winter flounder from the most southerly population, Shinnecock Bay, initiated antifreeze peptide production at the same time of year (Nov) as did flounder from the most northern population (Newfoundland). Flounder from a geographically intermediate population. Passamaquoddy Bay, produced antifreeze peptides approximately 2 mo later (Jan). The differences observed did not correlate with differences in seawater temperatures. Antifreeze peptides disappeared from the plasma during March in the Shinnecock Bay flounder, April in the New Brunswick flounder, and May in the Newfoundland flounder. These differences correlated with the regional differences in the time at which the water temperature increased. It is hypothesized that the time of antifreeze production is a genetically determined population characteristic which reflects the earliest date that antifreeze peptides would be essential to their survival.
\end{abstract}

\section{INTRODUCTION}

Winter flounder inhabit the inshore coastal areas of Atlantic Canada and northeastern United States throughout the year. Many of these areas are characterized by the presence of ice and subzero $\left(-1.4^{\circ} \mathrm{C}\right)$ water temperatures (Fletcher, 1977; Petzel et al., 1980). Extensive investigations over the past $10 \mathrm{yr}$ have resulted in a considerable body of information indicating that winter flounder cope with these freezing conditions by synthesizing antifreeze proteins and secreting them into the blood during the winter (Duman and DeVries, 1974, 1976; Hew and Yip, 1976). In a recent study of the plasma antifreeze proteins from Newfoundland winter flounder, at least 7 active components were found, 5 of 3,300 daltons and 2 of approximately 4,500 daltons (Fourney et al., 1984a). These polypeptides lower the freezing point of the blood plasma in a non-colligative manner, that is, they lower the temperature at which ice will form, but do not lower the melting temperature of the ice (DeVries, 1983).
In Newfoundland, the annual cycle of plasma antifreeze levels correlates closely with the annual cycle of seawater temperature. Antifreeze proteins appear in the plasma during November when the water temperature approximates 4 to $6^{\circ} \mathrm{C}$ and disappear during May when the temperature generally rises above $0^{\circ} \mathrm{C}$ (Fletcher, 1977). In a study of a population of Nova Scotian flounder, plasma antifreeze levels were found to increase approximately 1 mo later and decline 2 mo earlier than they did in Newfoundland flounder. These differences between the 2 populations correlated with the regional differences in the annual cycles of seawater temperature (Fletcher and Smith, 1980). At this time, Petzel et al. (1980) published the annual cycle of plasma antifreeze levels in flounder inhabiting Shinnecock Bay, a shallow bay on the southeastern shore of Long Island, New York. When these investigators compared their results for Shinnecock Bay flounder with those published for Newfoundland flounder, they found that the time at which antifreeze peptides appeared in the plasma was essentially the same. A comparison of the Shinnecock Bay, Nova Sco- 
tian and Newfoundland water temperatures immediately preceding and during the time of antifreeze appearance in the plasma (Oct to Dec) revealed that Shinnecock Bay and Nova Scotia were essentially the same, and that the seasonal decline in the water temperatures of both areas lagged behind Newfoundland by approximately a month (Fletcher and Smith, 1980; Petzel et al., 1980). Thus, antifreeze proteins appear in the plasma of Shinnecock Bay flounder at water temperatures of approximately 8 to $10^{\circ} \mathrm{C}$, while in Newfoundland and Nova Scotian flounder they appear at temperatures of 4 to $6^{\circ} \mathrm{C}$ (Fig. 5). Two questions arose from these observations: (1) Since Newfoundland and Shinnecock Bay flounder make antifreeze proteins at the same time of year, why does the geographically intermediate population of Nova Scotian flounder synthesize antifreeze peptides one month later? (2) Why do Shinnecock Bay flounder appear to synthesize antifreeze proteins so much more in advance of winter water temperatures than do the Nova Scotian and Newfoundland flounder?

Since the methods used to estimate the antifreeze levels differed between the studies of Petzel et al. (1980) and Fletcher and Smith (1980), it seemed possible that the differences between the Shinnecock Bay flounder and their more northern counterparts could be more apparent than real. Therefore, the present study was carried out to compare the annual plasma antifreeze cycles of flounder from Shinnecock Bay, Long Island, and Chapel's Cove, Newfoundland using the same methods. In addition the annual antifreeze cycle was examined in a population of winter flounder from Passamaquoddy Bay, New Brunswick, which is located at a latitude intermediate between Newfoundland and Long Island.

\section{MATERIALS AND METHODS}

Winter flounder Pseudopleuronectes americanus were collected at approximately monthly intervals (Sep 1980 - Dec 1981) from the following 3 areas: Chapel's Cove, Conception Bay, Newfoundland

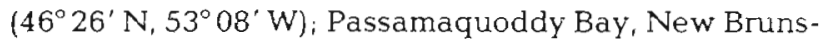
wick $\left(45^{\circ} 05^{\prime} \mathrm{N}, 67^{\circ} \mathrm{W}\right)_{i}$ and Shinnecock Bay, Long Island, New York $\left(40^{\circ} 52^{\prime} \mathrm{N}, 72^{\circ} 28^{\prime} \mathrm{W}\right)$. In Newfoundland the fish were caught in 10 to $20 \mathrm{~m}$ of water by divers using SCUBA (Fletcher, 1977), Passamaquoddy Bay fish were caught in 50 to $100 \mathrm{~m}$ of water using a Western trawl and in Shinnecock Bay they were caught in 2 to $4 \mathrm{~m}$ of water using a small otter trawl (Petzel et al., 1980). Newfoundland flounder were either bled immediately following capture $(30 \mathrm{~min})$ or maintained in the laboratory for 1 wk under seasonally ambient conditions of temperature and photoperiod
(Fletcher, 1977). Passamaquoddy Bay flounder were maintained in the Biological Station, St. Andrews, New Brunswick under ambient conditions of temperature and photoperiod for seven days before bleeding. Flounder from Shinnecock Bay could not be held in a healthy condition for seven days, therefore they were bled as soon after capture as possible (Petzel et al., 1980).

At all locations blood was obtained from a caudal blood vessel using 21 gauge syringe needles and stored in 2 to $4 \mathrm{ml}$ Vacutainers (Becton Dickinson) containing sodium heparin. The cells were separated from plasma using low speed centrifugation $(\sim 4,000 \mathrm{~g})$.

Plasma freezing point depression was measured using an Advanced Osmometer (Model 3D or 3R, Advanced Instruments Inc., MA, USA). Plasma $\mathrm{Cl}^{-}$was measured using a chloride titrator (Radiometer Copenhagen, model CMT 10). The antifreeze component of the plasma freezing point depression was approximated by subtracting the freezing point depression attributable to $\mathrm{NaCl}$. When the antifreeze activity values are greater than $0.1^{\circ} \mathrm{C}$ this method gives a reasonably good approximation of the antifreeze activity present in the plasma. Values of $0.1^{\circ} \mathrm{C}$ or less are commonly observed in flounder with little or no antifreeze peptides present and are believed to be attributable to the combined effects of electolytes other than $\mathrm{NaCl}$, and compounds such as glucose, amino acids, ammonia and urea (Duman and DeVries, 1976; Fletcher 1977; Fletcher and Smith, 1980; Slaughter and Hew, 1982). $\mathrm{Cl}^{-}$concentrations were converted to $\mathrm{NaCl}$ concentrations by the following equation: $\mathrm{NaCl}$ $(\mathrm{mM} / \mathrm{L})=\mathrm{Cl}^{-}(\mathrm{mM} / \mathrm{L}) \times 1.08$. The constant 1.08 was established from $\mathrm{Na}^{+}$and $\mathrm{Cl}^{-}$analysis of flounder plasma (Fletcher, 1975, 1977). Freezing point depression of $\mathrm{NaCl}=\mathrm{NaCl}(\mathrm{mM} / \mathrm{L}) \times 0.00343$. The constant 0.00343 was obtained from Weast and Selby (1967).

Antifreeze polypeptides were measured in the winter plasma samples by radioimmunoassay using antisera raised against gluteraldehyde polymerized antifreeze proteins according to the procedures outlined by Slaughter and Hew (1982).

A number of samples, covering a range of antifreeze polypeptide concentrations, were selected to determine their melting and freezing temperatures using a Clifton nanolitre osmometer. In this method the freezing temperature is the temperature at which a small seed ice crystal is observed to grow, and the melting temperature is the temperature at which it shrinks. Thermal hysteresis, a measure of antifreeze peptide activity, was calculated from the difference between the melting and freezing temperatures (DeVries, 1982).

All statistical comparisons were made using Student's t test (Steel and Torrie, 1960). 


\section{RESULTS}

\section{Plasma $\mathrm{Cl}^{--}$concentrations}

Plasma $\mathrm{Cl}^{-}$concentrations are very susceptible to the effects of capture stress. Therefore, flounder which are bled immediately after capture always have higher $\mathrm{Cl}^{-}$concentrations than those fish which have been allowed to recover for $1 \mathrm{wk}$ prior to bleeding (Fletcher. 1975, 1977). Shinnecock Bay flounder were bled soon after capture whereas New Brunswick flounder were held in aquaria for $7 \mathrm{~d}$. In order to compare these areas with Newfoundland, two groups of Newfoundland flounder were examined, those which were bled immediately following capture (field fish) and those which were held in the laboratory for $7 \mathrm{~d}$ (laboratory fish).

The results obtained from the Newfoundland flounder were essentially the same as those reported in earlier studies (Fletcher, 1977; Fletcher and Smith, 1980). The values for the field fish always exceeded those of the laboratory fish throughout most of the year,

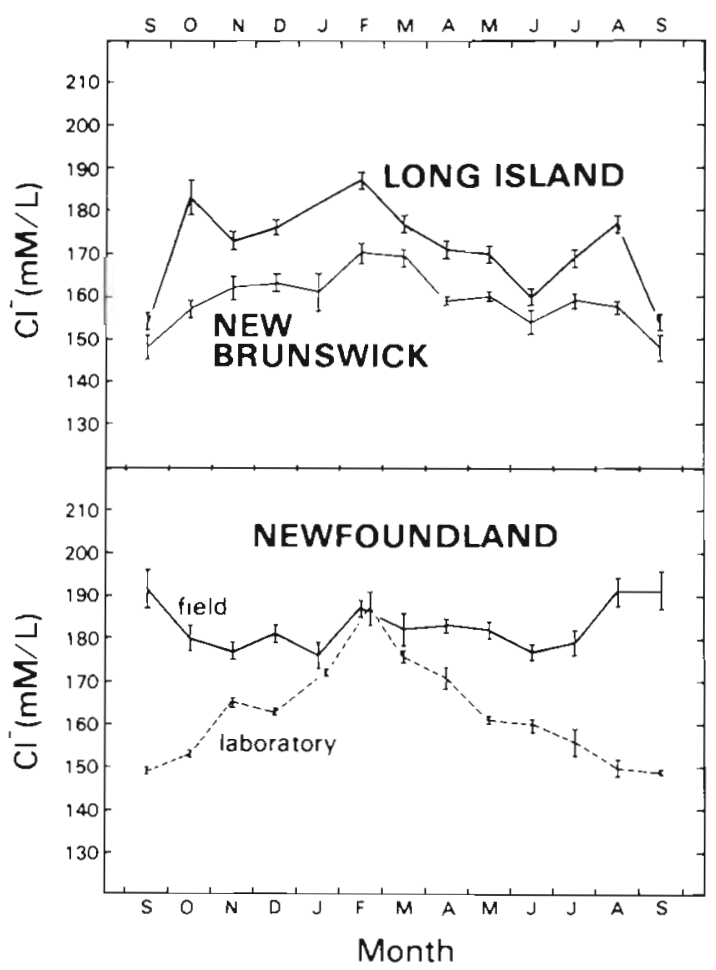

Fig. 1. Pseudopleuronectes americanus. Seasonal changes in plasma $\mathrm{Cl}^{-}$in winter flounder collected from Shinnecock Bay Long Island, Passamaquoddy Bay New Brunswick, and Chapel's Cove Newfoundland. Number of samples collected per month: Long Island, 11 to 24 ; New Brunswick, 6 to 16; Newfoundland, 14 to 20. Field: blood was collected immediately after capture; laboratory: blood was collected $7 \mathrm{~d}$ following capture. All values expressed as means \pm 1 standard error but more particularly from August through November (Fig. 1). Peak values for both groups of fish occurred during the cold winter months.

Plasma $\mathrm{Cl}^{-}$concentrations in the New Brunswick flounder showed a distinct seasonal cycle with the highest values occurring during February and March. During winter the plasma $\mathrm{Cl}^{-}$concentrations of the New Brunswick flounder were always lower than those observed in the Newfoundland laboratory held flounder. Salinities do not differ greatly between these two areas (32 to $33 \%$ ), therefore, the higher plasma concentrations found in the Newfoundland flounder may be attributable to Newfoundland's lower winter water temperatures.

Plasma $\mathrm{Cl}^{-}$concentrations also showed a seasonal cycle in Shinnecock Bay flounder, although it was less distinct than that of the New Brunswick flounder and the Newfoundland laboratory flounder. Since the Shinnecock Bay flounder were bled soon after capture the results are comparable to those of the Newfoundland field flounder. Peak $\mathrm{Cl}^{-}$values in the Shinnecock Bay flounder were observed during February. This was followed by a decline to a low value in June and an abrupt increase during July and August (Fig. 1). This summer increase is reminiscent of the similar summer increase observed in the Newfoundland field flounder and is possibly due to an enhancement of capture stress which appears to take place during the period of warmer water temperatures (Fletcher, 1975, 1977). The decline between August and September was similar to that not infrequently observed in Newfoundland field flounder (Fletcher, 1977).

\section{Plasma antifreeze activity and antifreeze polypeptide levels}

Newfoundland field and laboratory samples did not differ significantly from each other. Therefore, data for each month were combined to help simplify comparisons between populations. Plasma antifreeze activity increased above summer values during November in the Shinnecock Bay and Newfoundland samples. A similar increase did not occur in the New Brunswick samples until January. Peak values occurred from December through April in Newfoundland, December through February in Shinnecock Bay, and February and March in New Brunswick (Fig. 2). Plasma antifreeze activity declined during March in the Shinnecock Bay samples, April in the New Brunswick samples and May in the Newfoundland flounder (Fig, 2).

Plasma antifreeze polypeptide levels showed seasonal trends which were essentially the same as those observed for the antifreeze activity. Peak antifreeze peptide levels in the New Brunswick flounder were 


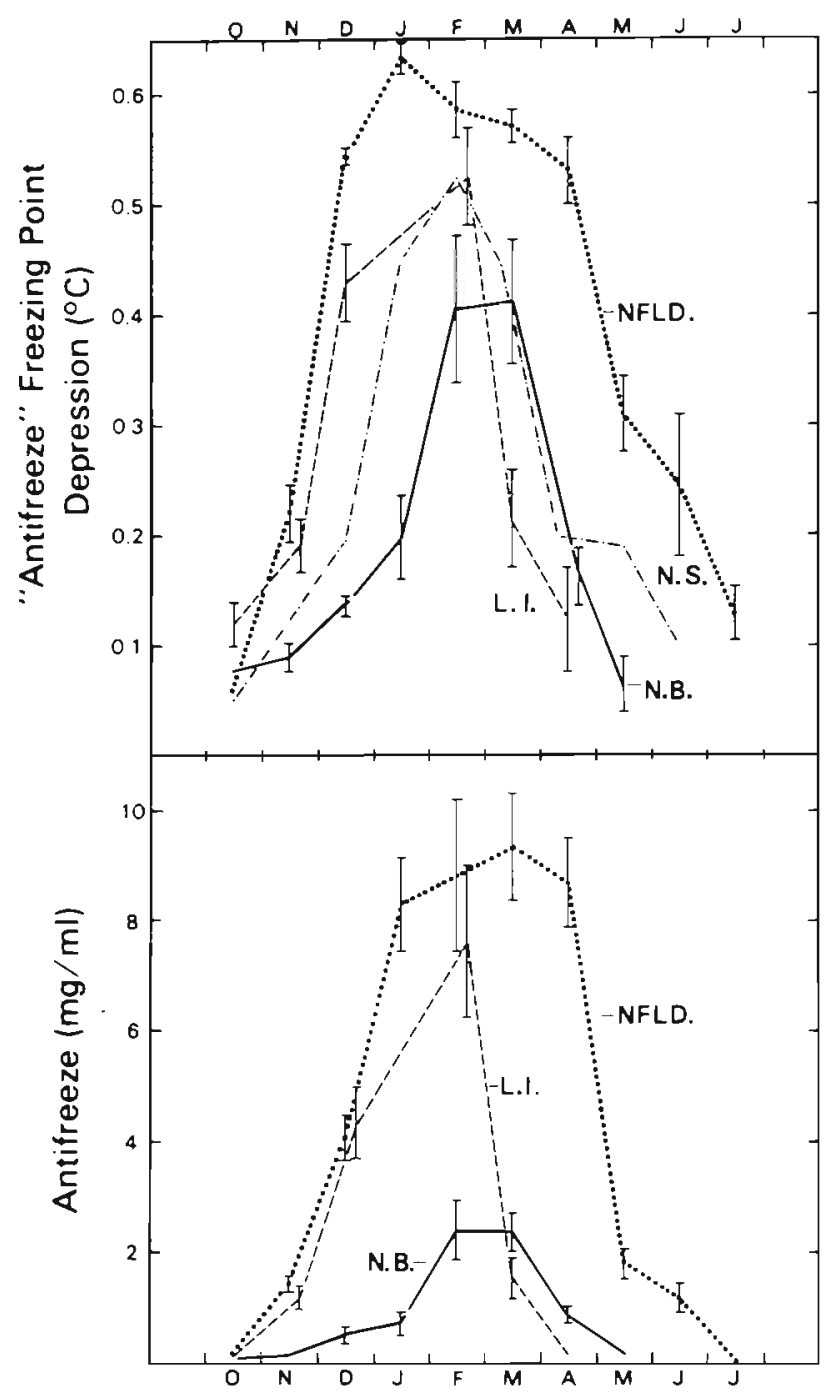

Fig. 2. Pseudopleuronectes americanus. Seasonal changes in plasma 'antifreeze' freezing point depression, and antifreeze peptide concentrations in winter flounder collected from Shinnecock Bay, Long Island (LI), Passamaquoddy Bay, New Brunswick (NB) and Chapel's Cove Newfoundland (NFLD). 'Antifreeze' freezing point depression values are also plotted for flounder from St. Margarets Bay Nova Scotia (NS). Data taken from Fletcher and Smith (1980). Number of samples analyzed per month: Long Island, 11 to 24; New Brunswick, 6 to 16; Newfoundland, 10 to 37 . All values expressed as means \pm 1 standard error

significantly lower than those in Newfoundland and Shinnecock Bay flounder (Fig. 2). Antifreeze peptide levels were also measured in plasma from Nova Scotian flounder $\left(44^{\circ} 37^{\prime} \mathrm{N}, 64^{\circ} 02^{\prime} \mathrm{W}\right)$ collected during October and December (Fletcher and Smith, 1980). The values obtained for October $(0.011 \pm 0.004$ (SE) $\mathrm{mg} \mathrm{ml}^{-1}, \mathrm{~N}=6$ ) were similar to those observed for the other locations (Fig. 2). December values for the Nova Scotian flounder were $1.45 \pm 0.39 \mathrm{mg} \mathrm{ml}^{-1}(\mathrm{~N}=7)$. This value was similar to those of Newfoundland and

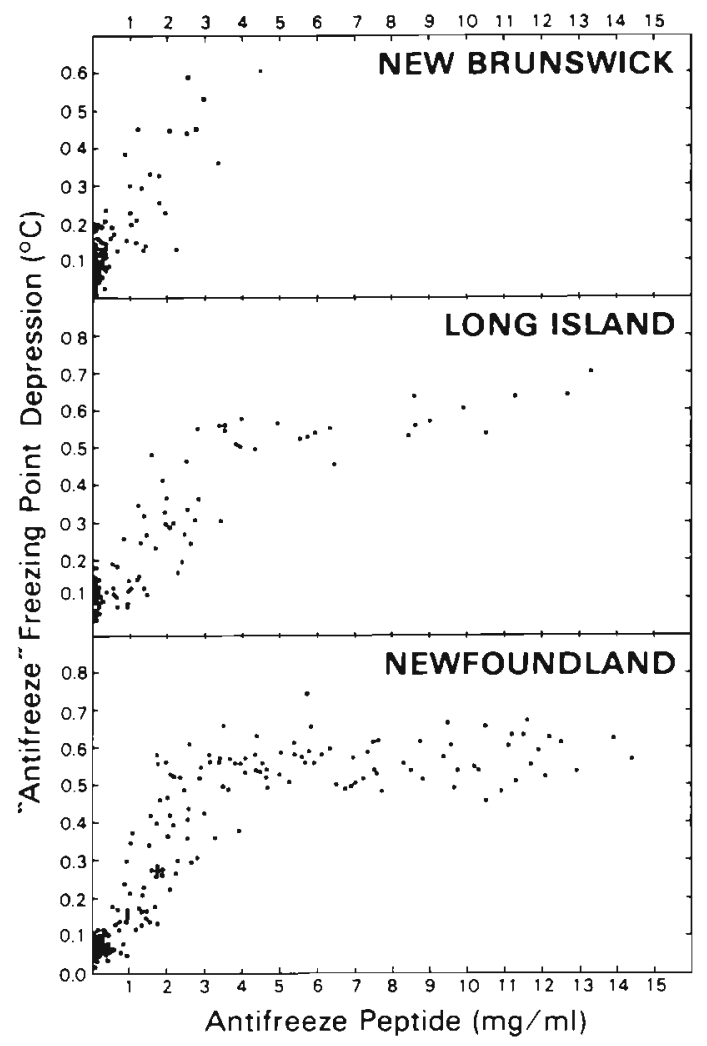

Fig. 3. Pseudopleuronectes americanus. Relations between plasma 'antifreeze' freezing point depression and antifreeze peptide concentrations

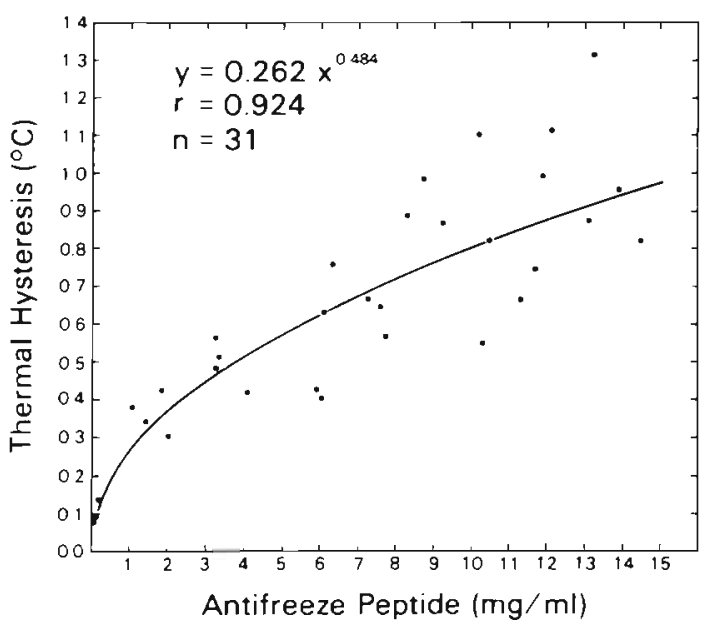

Fig. 4. Pseudopleuronectes americanus. Relation between plasma thermal hysteresis and antifreeze peptide concentration in Newfoundland winter flounder

Shinnecock Bay flounder $(1.43 \pm 0.13, \mathrm{~N}=37$, and $1.19 \pm 0.19, \mathrm{~N}=24$, respectively) in November, and lower $(\mathrm{P}<0.001)$ than the December values for Newfoundland $\left(4.00 \pm 0.43 \mathrm{mg} \mathrm{ml}^{-1}, \mathrm{~N}=21\right)$ and Shinnecock Bay flounder $\left(4.33 \pm 0.65 \mathrm{mg} \mathrm{ml}^{-1}, \mathrm{~N}=22\right)$. In addition, the December concentrations of Nova Scotian 


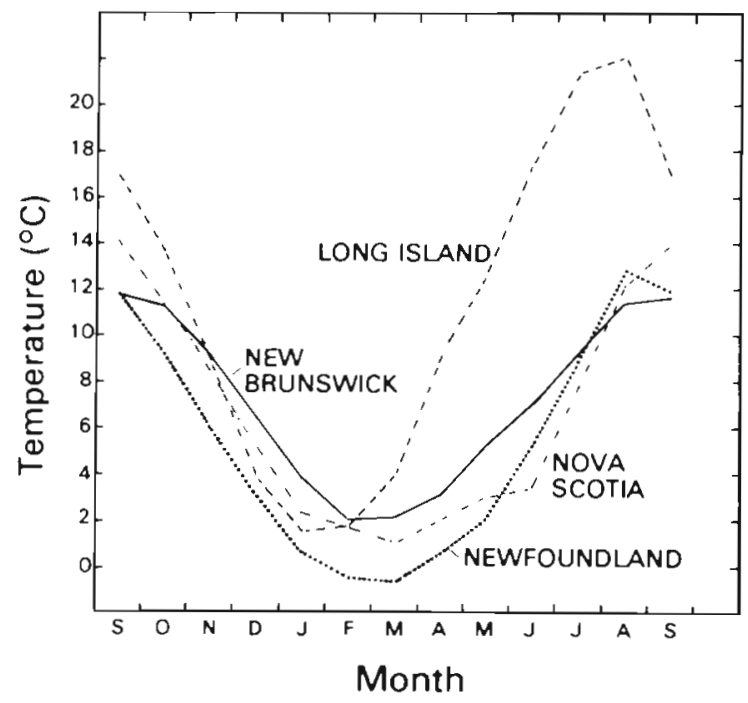

Fig. 5. Seasonal changes in sea water temperatures

flounder were greater $(\mathrm{P}<0.05)$ than those of New Brunswick flounder $\left(0.519 \pm 0.15 \mathrm{mg} \mathrm{ml}^{-1}, \mathrm{~N}=14\right)$.

The relation between plasma antifreeze activity and antifreeze polypeptide concentration was plotted for all 3 locations studied (Fig. 3). The general shapes of the curves do not differ between populations and the antifreeze activity in the Newfoundland and Long Island flounder begins to plateau at antifreeze peptide levels above $4 \mathrm{mg} \mathrm{ml}^{-1}$. Thermal hysteresis was determined in a number of Newfoundland flounder plasma samples with antifreeze peptide concentrations ranging from 0.2 to $14.5 \mathrm{mg} \mathrm{ml}^{-1}$. The relation between antifreeze concentration and thermal hysteresis is plotted in Fig. 4. This curve is essentially the same as that reported for purified flounder antifreeze peptide (Duman and DeVries, 1976). Unlike the antifreeze activity measurements plotted in Fig. 3, thermal hysteresis values did not appear to reach a plateau.

\section{Water temperature}

Seasonal cycles of water temperature for the locations studied are presented in Fig. 5. In Newfoundland the temperatures were measured at depths of 5 to $15 \mathrm{~m}$. The values represent monthly averages for a $10 \mathrm{yr}$ period (1973-1982) (Fletcher, 1977; Fletcher et al., 1978; Fletcher and Smith, 1980; Hew et al., 1980; Fletcher et al., 1982). New Brunswick water temperatures were recorded at depths of 30 to $50 \mathrm{~m}$ in Passamaquoddy Bay, just offshore from the Biological Station, St. Andrews (unpubl. data). Values represent monthly averages for a 12 yr period (1970-1981). These temperatures do not differ from those obtained at the site where the flounder were captured (Fletcher et al.,
1984). Shinnecock Bay water temperatures were measured at the surface to $4 \mathrm{~m}$. Values represent the monthly average of values collected over a period of 3 to 6 yr (1966-1982) (Moeller, 1969; Petzel et al., 1980; Reisman et al., 1984). St. Margarets Bay, Nova Scotia values were taken from Fletcher and Smith (1980).

\section{DISCUSSION}

The time at which antifreeze peptides appear in the plasma of Newfoundland winter flounder (Nov) has been shown to be remarkably constant from year to year (Fletcher, 1977; Fletcher et al., 1978; Fletcher and Smith, 1980). The same conclusion was evident from a two year study of Nova Scotian flounder. However, levels of antifreeze activity comparable to those of Newfoundland flounder did not occur in the plasma of flounder from Nova Scotia until December; 1 mo later than in Newfoundland (Fletcher and Smith, 1980). Moreover, when Nova Scotian flounder were transferred to Newfoundland they retained their Nova Scotian antifreeze cycle (Fletcher and Smith, 1980).

The results of the present investigation demonstrate that winter flounder from the most southerly population studied, Shinnecock Bay Long Island, initiate plasma antifreeze peptide production at the same time of year (Nov) as do flounder from the most northern population (Newfoundland). In contrast flounder from a geographically intermediate population, Passamaquoddy Bay, New Brunswick, produced antifreeze peptides 1 to 2 mo later than flounder from Newfoundland and Shinnecock Bay, and 1 mo later than Nova Scotian flounder (Fig. 2). All of these studies suggest that the time of onset of antifreeze production in winter flounder is a population characteristic. The question arising from this conclusion is: why does the time of antifreeze production differ between populations?

Previous studies have indicated that the annual antifreeze cycle may be endogenous, with photoperiod, not temperature, acting as the zeitgeber for entraining the precise time of initiation of antifreeze synthesis in early winter (Fletcher and Smith, 1980; Fletcher, 1981). The present study established that there is no correlation between latitude and the time of antifreeze appearance in the blood. Therefore, the photoperiodic cue, or the response it evokes in the flounder, must differ between populations. Since annual rhythms appear to be genetically controlled (Murton and Kear, 1973; Pengelley and Asmundson, 1974), the population differences observed in the timing of the annual antifreeze cycle could reflect genotypic differences.

It has become apparent over the past $10 \mathrm{yr}$ of study that the Newfoundland winter flounder synthesize antifreeze proteins well before they are required to 
prevent them from freezing (Fletcher, 1977; Fletcher and Smith, 1980). Although the reasons why the initiation of antifreeze synthesis takes place by a relatively specific date are unknown, it seems reasonable to assume that the winter flounder's strategy is to balance the time at which it must incur the metabolic costs of synthesizing antifreeze peptides against the time at which there may be a significant danger of freezing. Our scant knowledge concerning the seasonal biology of different flounder populations makes it difficult to ascertain the earliest date antifreeze proteins would be required in order to play a significant role in the survival of these populations.

One hypothesis prompted by the results of the present study is that the differences between the dates of antifreeze production in the populations studied reflect differences in the earliest dates antifreeze peptides would be essential. This hypothesis answers questions posed in the introduction and above discussion by suggesting that flounder populations are genetically programmed to produce adequate antifreeze levels in time for their earliest possible exposure to ice and subzero water temperatures. Clearly, the date at which these conditions occur at a particular geographical location could vary considerably from year to year, and may never occur at all during some winters. We do not know the role freezing mortality plays in selecting the appropriate gene pool for specific environmental conditions. Thus, during the course of relatively short-term studies, it would be difficult to detect the environmental reason why populations differ in the time at which they produce antifreeze peptides.

During winter, Newfoundland water temperatures are considerably colder than those of Nova Scotia, New Brunswick and Long Island (Fig. 5). In addition, subzero water temperatures and ice are common during early January and can occur during December. Furthermore, the water can be very stormy during December, resulting in ice crystals being driven deep into the water column. Thus, winter flounder residing in the inshore Newfoundland locations would appear to require antifreeze peptides prior to this time.

Shinnecock Bay, Long Island is very shallow, with an average depth of $2 \mathrm{~m}$ at mean low water. This results in the annual cycle of water temperature closely following the air temperature (Moeller, 1969). In all of the other locations studied the maximum and minimum water temperatures lag behind the air temperatures by approximately 1 mo (Steele, 1975). The lowest water temperatures occur in Shinnecock Bay during January and February, and in 3 separate studies, including the present one, considerable amounts of ice were present during January (Moeller, 1969; Petzel et al., 1980). The shallow depth of the bay and the rapidity with which the water temperatures follow the air temperatures signify that flounder would probably have to be prepared for freezing conditions as early as the Newfoundland flounder. Reisman et al. (1984) discuss the impact this shallow ice-laden habitat has on antifreeze production in the tomcod. Furthermore, the slightly lower salinities (25 to $33 \%$ ) of the Shinnecock Bay habitat, owing to near-shore freshwater runoff and groundwater seepage, create frequent winter surface ice conditions. This is another environmental factor that would select for high antifreeze activity in Shinnecock Bay flounder.

The winter flounder from Passamaquoddy Bay, New Brunswick and St. Margarets Bay, Nova Scotia were sampled from relatively deep water (50 to $100 \mathrm{~m}$, New Brunswick; 15 to $30 \mathrm{~m}$, Nova Scotia). At these depths, water temperatures have not been observed below $2^{\circ} \mathrm{C}$ in New Brunswick and rarely go below $0^{\circ} \mathrm{C}$ in Nova Scotia (Levings, 1972). Thus flounder inhabiting these locations are never in any danger of freezing. However, previous studies of flounder inhabiting St. Margarets Bay (Levings, 1972) and Passamaquoddy Bay (McCracken, 1963; Tyler, 1971) indicate that they move seasonally between deep and shallow water. Therefore, it is likely that flounder captured in deeper water have inhabited shallow areas of the bays at some time during their life cycle. The shallow waters at the head of St. Margarets Bay (within $2 \mathrm{~km}$ of the sampling area) which are well protected from storms, are characterized by sub-zero water temperatures and ice during the period of January to March. Levings (1972) has suggested that winter flounder overwinter in these ice covered areas. If this is the case the Nova Scotia flounder could require antifreeze proteins by January. Water temperatures in Passamaquoddy Bay, New Brunswick are generally warmer during the winter than any of the other areas under study. Surface water temperatures would be colder than those observed on the bottom, although subzero water temperatures, particularly below $-0.6^{\circ} \mathrm{C}$, and the presence of ice appear to be infrequent occurrences (Trites and Garrett, 1983). In addition, these low winter temperatures may not occur before February (Sutterlin et al., 1981). Thus, it may be that winter flounder residing in this area do not require antifreeze peptides until later than Newfoundland and Long Island populations.

The relatively warm waters of Passamaquoddy Bay may have reduced the essentiality of the antifreeze peptides to the survival of the majority of the winter flounder inhabiting this area. Interestingly, of the 4 populations studied the Passamaquoddy Bay flounder were the only ones to exhibit some degree of genetic polymorphism within their antifreeze peptides (Fourney et al., 1984b). For example, one of the major antifreeze components in the Passamaquoddy Bay flounder had the amino acid valine. This amino acid 
has not been observed in the major antifreeze components isolated from the other flounder populations (Fourney et al., 1984b).

The problem of defining winter flounder population units has been discussed by a number of investigators (Lux et al., 1970; Howe and Coates, 1975; Pierce and Howe, 1977; Haedrich, 1983). If, as this study suggests, winter flounder populations have genetically determined annual antifreeze biosynthetic cycles which are adapted to the annual cycle of freezing conditions of their particular environment, then it should be possible to distinguish between certain spawning units. For example, the shallow Long Island bays, including Shinnecock Bay, are interconnected with each other, but almost completely cut off from the ocean. Therefore it is possible that flounder populations in these bays interbreed with one another but not with populations inhabiting the ocean in the same vicinity. Since ocean temperatures would lag behind air temperatures the initiation of antifreeze production by an ocean population of winter flounder should occur later than in Shinnecock Bay flounder. In this regard it would be interesting to study the more offshore populations of winter flounder on Georges Bank where winter water temperatures are normally warmer than the inshore areas (Lux et al., 1970) and the danger from freezing minimal or non existent.

In Newfoundland, winter flounder antifreeze biosynthesis ceases during late February and March (Hew et al., 1979; Davies and Hew, 1980; Pickett et al., 1983; Fourney et al., 1984c). From this point in time the rate at which antifreeze peptides disappear from the plasma appears to be largely dependent on water temperature (Fletcher, 1981). The results of the present study are in agreement with this conclusion for there was a direct correlation between the dates at which antifreeze levels declined and the dates of water temperature increased (compare Fig. 2 and 5).

It is worthwhile to compare the 2 commonly used methods for estimating plasma antifreeze protein activity; the freezing point osmometer and direct crystal observation. The relation between antifreeze peptide concentration and antifreeze activity was essentially the same for both methods up to a concentration of $4 \mathrm{mg} \mathrm{ml}^{-1}$. However, at higher antifreeze peptide concentrations the freezing point osmometer method underestimated the antifreeze activity compared with the ice crystal method. Underestimations of antifreeze activity using a freezing point osmometer have been observed for a number of antifreeze peptides and glycopeptides (DeVries, 1982; Fletcher et al., 1984). Precisely why this happens is unknown but it appears to be related to the degree to which the samples are supercooled prior to the initiation of freezing, that is, if a sample containing these antifreezes is supercooled by 4 to $6^{\circ} \mathrm{C}$ before freezing is initiated, as is the case with the freezing point osmometer, the freezing point depression will be reduced considerably. Supercooling is avoided when methods involving direct observations of ice crystal growth are employed (DeVries, 1982).

Acknowledgements. We would like to thank Brenda Waiwood and Lou Van Eeckhaute of St. Andrews, N. B. and staff members of the Southampton College Marine Sciences Centre (D. Aldrich, C. Dalmasse, G. Garland, D. Getz, S Heins, T. Johnson) for assistance in collecting the flounder and obtaining blood samples. Alice Cadigan assisted with the chemical analysis and Dr. Ming Kao carried out the thermal hysteresis measurements. Dr. Choy Hew kindly supplied us with the flounder antifreeze antibody and Dr. Richard Haedrich provided constructive criticism on the manuscript. This research was supported by the Canadian Natural Sciences and Engineering Research Council (G.L.F.) M.S.R.L. Contribution Number 575 .

\section{LITERATURE CITED}

Davies, P. L., Hew, C. L. (1980). Isolation and characterization of antifreeze protein messenger RNA from the winter flounder. J. biol. Chem. 225: 8729-8734

DeVries, A. L. (1982). Biological antifreeze agents in cold water fishes. Comp. Biochem. Physiol. 73A: 627-640

DeVries, A. L. (1983). Antifreeze peptides and glycopeptides in cold water fishes. A. Rev. Physiol 45: 245-260

Duman, J. G., DeVries, A. L. (1974). Freezing resistance in winter flounder Pseudopleuronectes americanus. Nature, Lond. 247: 237-238

Duman, J. G., DeVries, A. L. (1976). Isolation, characterization and physical properties of protein antifreeze from the winter flounder, Pseudopleuronectes americanus. Comp. Biochem. Physiol. 54B: 375-380

Fletcher, G. L. (1975). The effects of capture 'stress' and storage of whole blood on the red blood cells, plasma proteins, glucose, and electrolytes of winter flounder (Pseudopleuronectes americanus) Can. J. Zool. 53: 197-206

Fletcher, G. L. (1977). Circannual cycles of blood plasma freezing point and $\mathrm{Na}^{+}$and $\mathrm{Cl}^{-}$concentrations in Newfoundland winter flounder (Pseudopleuronectes americanus) correlation with water temperature and photoperiod. Can. J. Zool. 55: 789-795

Fletcher, G. L. (1981). Effects of temperature and photoperiod on the plasma freezing point depression, $\mathrm{Cl}^{-}$concentration, and protein 'antifreeze' in winter flounder. Can. J. Zool. 59: 193-201

Fletcher, G. L., Smith, J. C. (1980). Evidence for permanent population differences in the annual cycle of plasma antifreeze' levels of winter flounder. Can. J. Zool. 58: 507-512

Fletcher, G. L., Campbell, C. M., Hew, C. L. (1978). The effects of hypophysectomy on seasonal changes in plasma freezing point-depression, protein 'antifreeze' and $\mathrm{Na}^{+}$ and $\mathrm{Cl}^{-}$concentrations of winter flounder (Pseudopleuronectes americanus). Can. J. Zool. 56: 109-113

Fletcher, G. L., Slaughter, D., Hew, C. L. (1982). Seasonal changes in plasma levels of glycoprotein antifreeze, $\mathrm{Na}^{+}$. $\mathrm{Cl}^{-}$, and glucose in Newfoundland Atlantic cod (Gadus morhua). Can. J. Zool. 60: 1851-1854

Fletcher, G. L., Kao, M. H., Haya, K. (1984). Seasonal and phenotypic variations in plasma protein antifreeze levels 
in a population of marine fish (sea raven, Hemitripterus americanus). Can. J. Fish. aquat. Sci. 41. 819-824

Fourney, R. M., Joshi, S. B., Kao, M. H., Hew, C. L. (1984a). Heterogeneity of antifreeze polypeptides for the Newfoundland winter flounder, Pseudopleuronectes americanus. Can. J. Zool. 60: 28-33

Fourney, R. M., Hew, C. L., Joshi, S. B., Fletcher, G. I. (1984b). Comparison of antifreeze polypeptides from Newfoundland, Nova Scotia, New Brunswick and Long Island winter flounder Comp. Biochem. Physiol. 78B: 791-796

Fourney, R. M., Fletcher, G. L., Hew, C. L. (1984C). The effects of long day length on liver antifreeze mRNA in the winter flounder Pseudopleuronectes americanus. Can. J. Zool 62: $1456-1460$

Haedrich, R. L. (1983). Estuarine fishes. In: Ketcham, B. H. (ed.) Estuaries and enclosed seas. Elsevier Scientific Publishing Company, Amsterdam, p. 183-207

Hew, C. L., Yip, C. (1976). The synthesis of freezing point depressing protein of the winter flounder (Pseudopleuronectes americanus) in Xenopus laevis oocytes. Biochem. Biophys. Res. Comm. 71: 845-850

Hew, C. L., Sclater, A., Fletcher, G. L. (1979). Biosynthesis and regulation of the antifreeze protein in the winter flounder Proceedings XI International Congress of Biochemistry. 8-13 July, Toronto, Canada Abst. No. 13-1-R115, p. 683

Hew, C. L., Fletcher, G. L., Ananthanarayanan, V S. (1980). Antifreeze proteins from the shorthorn sculpin, Myoxocephalus scorpius; isolation and characterization. Can. J. Biochem. 58: 377-383

Howe, A. B., Coates, P. G. (1975). Winter flounder movements, growth, and mortality off Massachusetts. Trans. Am. Fish. Soc 103: 13-29

Levings, C. D. (1972). A study of temporal change in a marine benthic community, with particular reference to predation by Pseudopleuronectes americanus (Walbaum) (Pisces: Pleuronectidae). Ph. D. thesis, Dalhousie University, Halifax, N.S., Canada

Lux, F. E., Peterson, A. E., Jr., Hutton, R. F. (1970). Geographical variation in fin ray number in winter flounder, Pseudopleuronectes americanus (Walbaum), off Massachusetts. Trans. Am. Fish. Soc. 99: 483-488

McCracken, F. D. (1963). Seasonal movements of the winter flounder, Pseudopleuronectes americanus (Walbaum), on the Atlantic coast. J. Fish. Res. Bd Can. 20: 551-586

Moeller, H. W. (1969). Ecology and life history of Codium fragile subsp. tomentosoides. Ph. D. thesis, Rutgers University, New Jersey
Murton, R K., Kear, J. (1973). The nature and evolution of the photoperiodic control of reproduction in wild fowl of the family Anatidae. J. Reprod. Gent. 19 (Suppl.); 67-84

Pengelley, E. T., Asmundson, S. J. (1974). Circannual rhythmicity in hibernating mammals. In: Pengelley, E. T. (ed.) Circannual clocks. Academic Press Inc., New York, p. 95-110

Petzel, D. H., Reisman, H. M., DeVries, A. L. (1980). Seasonal variation of antifreeze peptide in winter flounder, Pseudopleuronectes americanus. J. exp. Zool. 211: 63-69

Pickett, M. H. Hew, C. L., Davies, P. L. (1983). Seasonal variation in the level of antifreeze protein mRNA from the winter flounder Biochem. biophys. Acta 739: 97-104

Pierce, D. E., Howe, A. B. (1977). A further study on winter flounder group identification off Massachusetts. Trans. Am. Fish. Soc. 106: 131-139

Reisman, H. M., Kao, M. H., Fletcher, G. L. (1984). Antifreeze glycoprotein in a 'Southern' population of Atlantic tomcod, Microgadus tomcod. Comp. Biochem. Physiol. 78A: $445-447$

Slaughter, D., Hew, C. L. (1982). Radioimmunoassay for the antifreeze polypeptides of the winter flounder: seasonal profile and immunological cross reactivity with other fish antifreezes. Can. J. Biochem. 60: 824-829

Steele, D. H. (1975). Temperature cycles at the Marine Sciences Research Laboratory, Logy Bay, Newfoundland. Naturaliste can. 102: 265-268

Steel, R. G. D., Torrie, J. H. (1960). Principles and procedures of statistics. McGraw-Hill Book Co. Inc., Toronto

Sutterlin, A. M., Henderson, E. B., Merrill, S. P., Saunders, R. L., Mackay, A. A. (1981). Salmonid rearing trials at Deer Island New Brunswick, with some projections on economic viability. Can. Fish. aquat. Sci. Tech. Rep. 1011: $1-27$

Trites, R. W., Garrett, C. J. R. (1983). Physical oceanography of the Quoddy Region. In: Thomas, M. L. (ed.) Marine and coastal systems of the Quoddy Region, New Brunswick. Canadian Special Publication of Fisheries and Aquatic Sciences 64 , p. 9-34

Tyler, A. V (1971). Periodic and resident components in communities of Atlantic Fishes. J. Fish. Res. Bd Can. 28: 935-946

Weast, R. C., Selby, S. M. (1967). Handbook of chemistry and physics, 48th ed. Chemical Rubber Co., Cleveland, Ohio, USA 